This item was submitted to Loughborough's Research Repository by the author.

Items in Figshare are protected by copyright, with all rights reserved, unless otherwise indicated.

\title{
Feedback through student essay competitions: what makes a good engineering lecturer?
}

PLEASE CITE THE PUBLISHED VERSION

http://www.engsc.ac.uk/journal/

\section{PUBLISHER}

(C) Higher Education Academy Engineering Subject Centre, Loughborough University

\section{VERSION}

VoR (Version of Record)

\section{LICENCE}

CC BY-NC-ND 4.0

\section{REPOSITORY RECORD}

Collins, Kate, and John Davies. 2019. "Feedback Through Student Essay Competitions: What Makes a Good Engineering Lecturer?”. figshare. https://hdl.handle.net/2134/9262. 
This item was submitted to Loughborough's Institutional Repository (https://dspace.lboro.ac.uk/) by the author and is made available under the following Creative Commons Licence conditions.

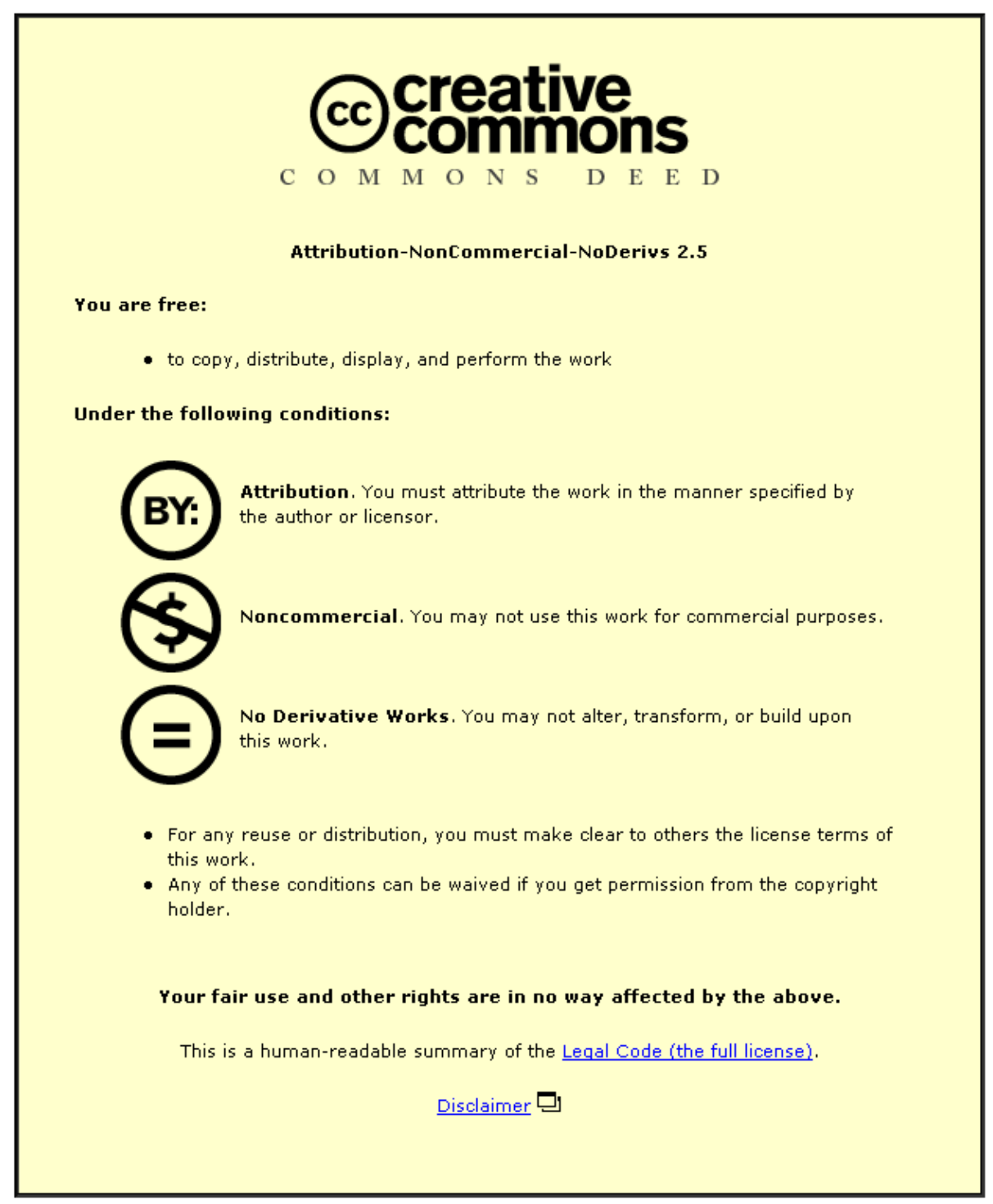

For the full text of this licence, please go to: http://creativecommons.org/licenses/by-nc-nd/2.5/ 


\title{
Feedback through student essay competitions: what makes a good engineering lecturer?
}

\author{
Kate Collins and John Davies
}

\begin{abstract}
The Engineering Subject Centre of the Higher Education Academy has run student essay competitions for some years. In 2007/08 the title was 'What makes a good engineering lecturer?'. This paper presents an analysis of the $\mathbf{4 3}$ submissions, carried out to identify the most commonly cited attributes and to present quotes that convey the spirit of the essays. The same title had been used for the first competition in 2003/04, and the outcomes of the 2007/08 competition are compared with those previously published for the 2003/04 award. The attributes most commonly identified across both sets of essays are use of real-world examples, approachability, enthusiasm, diversity of media, and good communication.

\section{Introduction}

The Engineering Subject Centre of the Higher Education Academy has run essay competitions entitled 'Student Awards' since 2003/04. The idea started from a simple desire to gather student views on engineering education. It was hoped that the shortlisted essays published on the website would be a useful resource for engineering lecturers. Another incidental but valuable aim was to increase the involvement of students with the subject centre.
\end{abstract}

The title for the first competition in 2003/04 was 'What makes a good engineering lecturer?'. The competition has been run every year since, with the titles given in Table 1. Each competition has generated some excellent submissions, which have been judged by a panel of academics, professional engineers and subject centre staff. Each year the essay written by the competition winner has been published on the Centre's website (www.engsc.ac.uk), together with a number of shortlisted entries. Since 2004/05 the competition has been run in collaboration with the majority of the other subject centres of the HE Academy (HE Academy, 2009) and the overall winner has been awarded a prize at the Academy's annual conference.

For the $2007 / 08$ competition it was decided to return again to 'What makes a good engineering lecturer?'.

The entries to the 2003/04 competition were analysed in some detail by Davies et al. (2006). The outcome was a list of favoured attributes with an indication of the level of consensus for each that was expressed in the essays. This was supported by quotations from the essays covering the most insightful and sincerely expressed comments.

Davies and Arlett (2006) made further comment on the 2003/04 competition. The paper describes the organisation of the competition and contains some reflection on the use of student essays in general as a feedback tool. The outcomes of the 2004/05 competition ('What makes the best learning experience for an engineering student?') were also considered, and the following observation was made:

Table 1. Essay competition titles

\begin{tabular}{|l|l|}
\hline Year & Title \\
\hline $2003 / 04$ & $\begin{array}{l}\text { What makes a good } \\
\text { engineering lecturer? }\end{array}$ \\
\hline $2004 / 05$ & $\begin{array}{l}\text { What makes the best learning } \\
\text { experience for an engineering } \\
\text { student? }\end{array}$ \\
\hline $2005 / 06$ & $\begin{array}{l}\text { How does your experience of } \\
\text { your course compare with any } \\
\text { expectations you may have had? }\end{array}$ \\
\hline $2006 / 07$ & $\begin{array}{l}\text { What advice would you give to } \\
\text { students starting your course? }\end{array}$ \\
\hline $2007 / 08$ & $\begin{array}{l}\text { What makes a good } \\
\text { engineering lecturer? }\end{array}$ \\
\hline $2008 / 09$ & $\begin{array}{l}\text { How can your classes be more } \\
\text { engaging? }\end{array}$ \\
\hline
\end{tabular}


'Perhaps because the students were less comfortable writing about themselves than they were writing about other people, the 2004/05 essays tend to be less lively - certainly less entertaining - than the $2003 / 04$ essays. Also, perhaps because there are more students than lecturers, or more learning styles than teaching styles, there is a less clear consensus in the 2004/05 essays.'

All the essay titles have produced fascinating thoughts and descriptions of personal experience, but the title 'What makes a good engineering lecturer?' seems to elicit a particularly lively response, and one that is particularly likely to arouse the curiosity of engineering academics. For that reason the $2007 / 08$ essays with this title have been analysed, and the findings form the main content of this paper.

The purpose is to present the views of the students in a readily accessible form, by identifying the most commonly identified attributes, and quoting from the content of the essays. The quotations are seen as an important element in this paper. The students are allowed to say it for themselves since they say it very well. There is also comparison of the views expressed in 2007/08 with those in 2003/04 (as reported by Davies et al. (2006)).

\section{The attributes identified}

All 43 essays submitted to the 2007/08 competition were analysed in order to identify the most commonly cited attributes, and to harvest quotations that elaborate on the attributes and give a sense of the liveliness and commitment of the essays.

Clearly there was some subjectivity on the part of the researchers in classifying the attributes, and there was some interpretation of the students' meaning in assuming that slightly different descriptions represented effectively the same attribute. This applies to the analysis of the $2007 / 08$ essays given below and to the analysis of the 2003/04 essays later in the paper.

In 2007/08, two attributes of good engineering lecturers were most frequently cited: approachability of lecturers (56\% of submissions) and the use of real-world examples in their teaching (also 56\%). There is a genuine excitement prevalent in many of the essays when the use of real-world examples is broached, for example:

'Change the world, invent the future - aspirations of a true engineer but is it possible? Yes, but only if there is a fusion between the academic and real worlds. Theoretical knowledge is useless unless it is applied to the bigger picture. Inspiring lecturers include videos, photographs, stories and information on historical context, related courses, research and applications of what I'm learning. They tell me the what, when, where, how and why which makes it worthwhile.'

(Hannah Latham, Engineering Tripos

- Mechanics and Materials (MEng) student at Cambridge University)

'The lessons I remember best are because the lecturer has said 'I am currently working on' and then suddenly the topic was not abstract anymore but it came to life.'

(Eileen Valera del Pino, Electronic Engineering student at King's College London)

'[...] a component should be shown to be part of a device which is an essential part of society, e.g. a mobile phone. This is a feature of engineering that causes it to differ from courses such as mathematics and physics and should be focused upon more.'

(Cara Morison,

Electronic and Electrical Engineering student at the University of Edinburgh)

Diversity of teaching tools/media also rated highly amongst the essayists (49\%), from both a point of view of holding the students' attention and encompassing the wide range of learning styles which will inevitably be colliding, as put by Fatuma Ali, Civil Engineering student at City University:

'The lecturers at the university realise that we all have different learning methods and set us work such as experiments. They use visual aids such as projectors and videos as well as good old fashioned books. This combination means that most students' needs are met.' 
Enthusiasm and passion for the subject are, like approachability, positive traits generic to all disciplines and obviously also rate highly amongst the entrants (42\%). Sarah Hunt, Electrical and Mechanical Engineering Student at the University of Edinburgh captures it well when she writes that

'the most important quality an engineering lecturer can have is to be genuinely interested in the subject that they teach.

[...] Enthusiasm is contagious and it encourages the student into further study of the subject, which in turn makes subsequent topics easier to understand.'

Communication skills are also of vital importance to our essayists (40\%). As Ben Pickard, foundation degree student at Lincoln College puts it,

'we can accept a lecturer's authority - obviously they've got there before us - but in order to pass on their knowledge they must be a reasonably skilled communicator, for without good communication there is nothing. Good communication, I feel, involves allowing the students time to let the info sink in and to check that they have understood it well.'

Claire McDonald, Mechanical Engineering student at Loughborough University goes on to say that

'good communication is best described in two ways: firstly the ability to present information in innovative and unusual ways while remaining easy to understand; secondly the ability to change the way they present material when it is unclear what they mean.'

So communication skills are gauged not only in terms of transmitting information but also in judging how well that information has been received and adjusting one's channel of transmission as necessary. Similarly, the ability to ascertain the skill level of one's cohort and adapt one's teaching style accordingly is high on the essayists agendas (30\% of the essays make reference to this):

'A good engineering lecturer identifies how different students learn and adapts to this. It makes sense that if we are all unique, we all have unique ways of learning.'

(Fatuma Ali, Civil Engineering student at City University.)
Notes and handouts provided by the lecturer rate very highly in the entrants' list of priorities (cited in 35\% of the essays), some favouring the 'fill in the gaps' kind as a way of ensuring attendance at lectures, but all in agreement that clarity and quality are of the utmost importance. Hannah Latham, Engineering Tripos - Mechanics and Materials (MEng) student at Cambridge University puts it well when she says:

\section{'[...] lecture notes - an engineering} lecturer's legacy (a big one anyway) to their students. Plot a graph of lecture note quality versus lecturer quality and you'll usually find a strong correlation. In some ways it is unsurprising - best lecturers usually write their own lecture notes creating invaluable resources I come back to time and again. Even a couple of years down the line they still give me fresh insights and understanding, teaching me long after the lectures have ended. They are worth their weight in gold.'

Hannah Latham, among $26 \%$ of the respondents, is also eloquent on the use of visual demonstration as part of an engineering lecturer's repertoire:
'Nearly all my memorable lectures contained a demonstration. I've experienced the delights of the ping pong canon, the electromagnetic missile launcher, robots, wind tunnels, gyroscopes and chocolate bears in bomb shelters in lectures. They help me understand and remember.'

Guagan Jackson, Civil and Coastal Engineering at the University of Plymouth also says that

'I find that an image of what I'm working out helps me focus and become fascinated $[. .$.$] '$

The standards expected by our essayists are high (and rightly so), but they don't just consider lecturing to be a one-way street. Interacting with the class, or 'audience participation', is cited in $26 \%$ of the essays as crucial to the success of the learning experience:

'Get everyone involved. A class should work as a team for maximum effectiveness. [...] Asking questions to 
the class gets the shyer pupils involved and keeps students focused.'

(Guagan Jackson, Civil and Coastal Engineering at the University of Plymouth.)

'[...] student participation is very effective, such as group presentations and class quizzes. This encourages personal research in the subject, increases confidence in public presentations and also brings fun to the class!'

(Roslyn Clarke, MEng Civil and Environmental Engineering student at the University of Edinburgh.)

The ability to inspire students is somewhat less tangible but rates almost as highly as interacting with them (23\%). Thomas Hickson, an Aeronautical and Aerospace Engineering student at the University of Leeds warns us that

'the fundamentals can be taught, presentations can be made and handouts can be distributed, however, if this process is devoid of inspiration aren't we in danger of turning the creative process of engineering into an exercise purely focused on passing exams rather than passing on the motivation to seek the knowledge and solutions to problems not yet conceived as well as those regimentally presented at the end of each semester?'

Slightly less apocalyptic is Thomas Hickson's contribution regarding the importance given to a firm command of the subject matter and current literature and development (an importance also stressed by $21 \%$ of the participants):

'To lecture is to pass on knowledge, and as a result, this knowledge is surely limited to that of the lecturer. This does not necessarily have to be the pure technical knowledge students are presented with, but also the means by which additional information can be ascertained, such as knowledge of relevant research papers, publication databases and connections with industry or academic specialists. As students we seek mentors that can present the fundamental foundations upon which future learning can be mapped and knowledge built.'
As they are demonstrating the tools and pointing in the right direction, the good lecturers (according to 19\% of essayists) are also encouraging students to think for themselves.

\section{'Not being content just with the traditional teaching, he is able to inspire his students to go on a quest for knowledge. Creating a sense of curiosity in the student so that it makes them to search more in the area through different sources and make them think innovatively is also part of teaching.'}

(Alex George Kanjirathinkal, Engineering and Management of Manufacturing

Sciences student at Cranfield University.)

On a more administrative note, a well organised and suitably prepared lecturer is one likely to make a good impression on 14\% of respondents. As Roslyn Clarke, MEng Civil and Environmental Engineering student at the University of Edinburgh puts it:

'Preparation is vital to gain student confidence in their knowledge and the information they provide - no one likes to wait for a lecturer to work out his own slides!'

A similar number of essays (12\%) cited clarity of course structure as key to a lecturer's success. Lauriane Thorner, MSc Control Systems student at Imperial College sums this up well:

'The first point that makes a good engineering lecturer is the clarity of his course. [...]Taking into account that only ten percent of what the lecturer says remain in the students' minds, he needs to know how to make them focus on the main ideas [...] a logical and explicit structure in the course is certainly the most reliable tool, all the more that examples and corrected-exercises illustrate the important steps and that the courses are well-organised.'

Surprisingly, given that the entrants were feeding back to their teachers in the broadest sense of the term by entering the competition only $12 \%$ of the essayists cited openness to student feedback as a trait of the good lecturer. One of the few who did, Benjamin Wang (a Mechanical Engineering Student at the University of Bristol), stressed the need to give as well as receive feedback: 
'It is essential for a good lecturer to both give feedback and take feedback through numerous forms. [...]Formally, feedback on the understanding and knowledge of the students can be gained by setting tests. [...] A good engineering lecturer should gain feedback on their quality of their teaching.'

The idea that at a lecturer's awareness of cultural diversity is crucial to the learning experience is mentioned in 9\% of the essays. Alex George Kanjirathinkal, Engineering and Management of Manufacturing Sciences student at Cranfield University stresses the sensitivity that this entails:

'The student mind is not a clean slate to be written on at this stage in their lives. Instead, each one comes with a different background and educational experience. Cross cultural and institutional differences also play a major role here. Being sensitive to this individuality is part of teaching and has to be kept in mind. The teacher needs to have the ability to empathise with the students with regard to the educational experience.'

All in all, the response from the student community has been overwhelmingly positive, both in terms of the number of essays and what they have to say. To close with a conclusion from the 2007/08 winner, Warren Rieutort-Louis (an Engineering student at Cambridge University):

'Good lecturers have such an impact on our studies, just like good teachers at school. My experience has led me to meet many such people that have irrevocably shaped the understanding of hundreds of students, through enthusiasm, through drive, through passion. They may not all have a 'Professor ABC appreciation society' on Facebook, but they will certainly have admiration and respect.'

This winning essay, the two other essays shortlisted from 2007/08, and all the shortlisted essays of earlier years, are available on the Engineering Subject Centre website (www.engsc. ac.uk).

\section{Comparison with 2003/04}

In response to the first use of the same essay title in 2003/04, 29 essays were submitted. It was the first competition, and the judging panel, perhaps keen to maximise exposure to the submissions on the website, shortlisted 11. In the analysis of these submissions (Davies et al., 2006) the level of consensus for the various attributes was derived from the 11 shortlisted submissions only, although all 29 essays were used as a potential source of quotations. It was not considered appropriate to give precise percentages based on a total of just 11, and so the level of consensus was expressed as:

- $\quad$ strong consensus - referred to in virtually all the shortlisted essays

- good consensus - referred to in more than half the shortlisted essays

- some consensus - referred to in several of the shortlisted essays.

The precise categorisation of the attributes identified in the essays was different for 2003/04 and 2007/08, partly because of the difference in the number of essays analysed (11 in 2003/04 against 43 for 2007/08), partly because the detailed analysis was carried out by different researchers, and partly because the essays themselves were different. In both cases, an element of 'grounded theory approach' was evident in the analysis in the sense that it was considered important to allow the categories to emerge from the data.

The attributes identified, and the level of consensus, for the 2003/04 essays were as follows.

Strong consensus - Virtually all the shortlisted essays referred to these characteristics: that a good engineering lecturer:

- is enthusiastic

- gives clear, well-structured presentations

- uses real-world engineering examples backed up by industrial experience.

Good consensus - The following characteristics were clearly identified in more than half of the shortlisted essays. A good lecturer:

- has a genuine interest in students as individuals and as members of an audience (is friendly, approachable and patient; is audience-aware and responds to feedback)

- encourages learning

- has depth of knowledge and command of the material

- uses visual material and demonstrations effectively 
- gives good handouts

- makes classes enjoyable.

Some consensus - In addition to these characteristics, several shortlisted essays indicated that a good engineering lecturer:

- is good at simplifying difficult concepts

- is well organised and reliable.

With fewer essays to analyse, it is not surprising that the analysis of 2003/04 essays divides the attributes more coarsely. The 2003/04 analysis is based on 11 attributes, whereas the 2007/08 is based on 16. For 2003/04, enthusiasm and ability to inspire were grouped together, whereas for 2007/08 they were treated separately. In 2003/04, a number of attributes were grouped under 'has a genuine interest in students as individuals and members of an audience', which for 2007/08 were treated separately as 'approachability', 'adaptability to student level', 'audience participation/ interaction', and 'openness to student feedback'.

An approximate comparison is given on Tables 2 and 3 . Table 2 gives the attributes in order of decreasing level of consensus based on the 2003/04 essays, and Table 3 gives the attributes in order of decreasing level of consensus based on the $2007 / 08$ essays.

Tables 2 and 3 show good agreement in the attributes identified in 2007/08 and in 2003/04, and in the level of consensus for each. Many of the apparent differences are the result of the differing approaches to defining the categories in the two separate analyses of essay content.

There are slight differences of emphasis overall: 'approachability', and 'adaptability to learning styles and student level' were emphasised more in 2007/08 whereas enthusiasm and enjoyment value were emphasised more in $2003 / 04$. It was observed by Davies et al. (2006) that in the 2003/04 essays 'no one comes remotely close to saying "a good lecturer is someone who doesn't lecture much". This is partly explained by the fact that ... these students have taken the title to refer to the lecturer as a giver of lectures.' Perhaps there is slightly more attention paid to the work of the lecturer outside the lecture room in the 2007/08 essays than in the $2003 / 04$ essays, but there is not enough data to confirm that this is a genuine change with time.

It is clear that both competitions gave high importance to use of real-world examples.

Table 2. Comparison of attributes based on $2003 / 04$ order

\begin{tabular}{|c|c|c|}
\hline \multicolumn{2}{|l|}{ 2003/04 } & $2007 / 08$ \\
\hline \multirow{3}{*}{ Strong consensus (virtually all) } & Enthusiasm & $\begin{array}{l}\text { Enthusiasm (42\%) } \\
\text { Ability to inspire (23\%) }\end{array}$ \\
\hline & Clear, well-structured presentations & Good communication (40\%) \\
\hline & Real-world examples & Real-world examples (56\%) \\
\hline \multirow{6}{*}{ Good consensus (more than half) } & $\begin{array}{l}\text { Interest in students as individuals } \\
\text { and members of audience }\end{array}$ & $\begin{array}{l}\text { Approachability (56\%) } \\
\text { Adaptability to student level (30\%) } \\
\text { Audience interaction (26\%) } \\
\text { Openness to feedback (12\%) }\end{array}$ \\
\hline & Encourages learning & $\begin{array}{l}\text { Encourages students to think for } \\
\text { themselves }(19 \%)\end{array}$ \\
\hline & Command of material & Command of subject (21\%) \\
\hline & Visual material and demonstrations & Diversity of tools/media (49\%) \\
\hline & Good handouts & Good handouts (35\%) \\
\hline & Classes enjoyable & \\
\hline \multirow{2}{*}{ Some consensus } & Simplifying difficult topics & Good communication (40\%) \\
\hline & Well organised & $\begin{array}{l}\text { Well organised/suitably prepared } \\
(14 \%)\end{array}$ \\
\hline
\end{tabular}


Table 3. Comparison of attributes based on $2007 / 08$ order

\begin{tabular}{|l|l|}
\hline $2007 / 08$ & $2003 / 04$ \\
\hline Approachability (56\%) & Interest in students (good) \\
\hline Use of real-world examples (56\%) & Real-world examples (strong) \\
\hline Diversity of teaching tools/media (49\%) & Visual material and demonstrations (good) \\
\hline Enthusiasm (42\%) & Enthusiasm (strong) \\
\hline Good communication skills (40\%) & Clear, well-structured presentations (strong) \\
\hline Good quality/clear lecture/handout notes (35\%) & Good handouts (good) \\
\hline Adaptability to student level (30\%) & Interest in students (good) \\
\hline Use of visual demonstration (26\%) & Visual material and demonstrations (good) \\
\hline Audience participation/interaction (26\%) & Interest in students (good) \\
\hline Ability to inspire (23\%) & Enthusiasm (strong) \\
\hline Having a firm command of subject matter (21\%) & Command of material (good) \\
\hline Encouraging students to think for themselves (19\%) & Encourages learning (good) \\
\hline Well organised/suitably prepared (14\%) & Well organised (some) \\
\hline Clarity of course structure (12\%) & \\
\hline Openness to student feedback (12\%) & Interest in students (good) \\
\hline Awareness of cultural diversity (9\%) & Interest in students (good) \\
\hline
\end{tabular}

(strong) $=$ strong consensus, virtually all essays

$($ good $)=$ good consensus, more than half

(some) $=$ some consensus

This is significant because there is concern about the decreasing number of engineering academics with industrial experience, resulting from pressure to recruit staff on the basis of research achievement. For example, the Joint Board of Moderators, the accrediting body that includes the Institutions of Civil and Structural Engineers, in its annual report of 2007 states that 'there continues to be pressure on Departments to recruit new staff with a proven research record ... exhortations for the recruitment process to put greater weight on new staff with appropriate professional and practical experience are too often falling on deaf ears' (Joint Board of Moderators, 2008)

\section{Conclusions}

The 43 essays with the title 'What makes a good engineering lecturer?' submitted in 2007/08 to the 'Student Award' competition organised by the Higher Education Academy Engineering Subject Centre have been analysed. The aim has been to identify the most commonly cited attributes and to present quotes that convey the spirit of the essays.
The outcome has been compared with a previously published analysis of 11 shortlisted essays with the same title submitted to the competition in $2003 / 04$. The comparison has been presented on Tables 2 and 3, which indicate a high level of agreement in the outcomes of the two competitions. The analysis of the $2007 / 08$ essays has produced a more finely-grained identification of attributes and their relative weighting by students entering the competition, which is useful in itself.

As in $2003 / 04$, the $2007 / 08$ essays should be of great value to engineering lecturers who are interested in what makes them, or might make them, good lecturers. But they are, above all, a source of inspiration. The students, even just through the quotations in this paper, communicate infectious enthusiasm - for their courses, for their future as engineers, and for their good lecturers.

\section{Acknowledgments}

The authors would like to acknowledge the contribution made by the students whose quotations have been used in this paper. 


\section{References}

Davies J.W., Arlett C., Carpenter S., Lamb F. and Donaghy L. (2006) What makes a good engineering lecturer? Students put their thoughts in writing. European Journal of Engineering Education, 31 (5), 543-553.

Davies J.W. and Arlett C. (2006) Essay competitions - valuable feedback from engineering students. Proceedings of the International Conference on Innovation, Good Practice and Research in Engineering Education, EE2006, Liverpool, 162-166.

HE Academy (2009) Student Awards 2009. www.heacademy.ac.uk [accessed 27 March 2009] Joint Board of Moderators (2008) Annual Report 2007. JBM, London.

\section{Contact details}

Kate Collins BA (Hons), Publications Assistant, Higher Education Academy Engineering Subject Centre, Loughborough University, Loughborough, LE11 3TU, UK.

Tel: 01509227170 Email: kate@engsc.ac.uk

Dr John W. Davies MSc, MA, PhD, CEng, FICE, FHEA, Head of Built Environment, Coventry University, Priory Street, Coventry, CV1 5FB, UK. Tel: 02476888095 Email: J.W.Davies@coventry.ac.uk 